\title{
Obituary
}

Professor J. L. JINKS, c.B.E., F.R.S,

It is with profound regret that the Editors note the death on 6 June 1987 of Professor Jinks. He was appointed a member of the Editorial Board in 1981, but his association with the Journal goes back over a much longer period as one of our most respected referees. Despite his onerous professional commitments, and more recently his ill health, he continued to undertake a large burden of work both as an Editor and in advising the Board of the Journal, and his wide and wise judgement was greatly respected. The Editorial Board record their deep gratitude for his contribution. 


\section{Plant Pathology}

An international journal edited by the British Society for Plant Pathology

Senior Editor

P.R. Scott

Plant Breeding Institute, Trumpington, Cambridge, UK
Deputy Editor

M.J.C. Asher

Bury St. Edmunds, UK

Editorial Board

K.W. Bailiss Wye

J.R. Coley-Smith Hull

S.A. Hill Harpenden

D.S. Ingram Cambridge

I.R. Crute Wellesbourne

G.J. Jellis Cambridge

C. Logan Belfast

D.L. Ebbels Harpenden

D.H. Lapwood Harpenden

C.M.E. Garrett East Malling

M. Gratwick Harpenden

E. Lester Harpenden

J.P. Ride Birmingham

D.J. Royle Bristol

R.C. Shattock Bangor

P.W. Talboys East Malling

B.G. Lewis Norwich

B.E.J. Wheeler Ascot

Plant Pathology publishes research papers and critical reviews on all aspects of the subject, including such topics as:

- Diseases of temperate and tropical plants caused by fungi, viruses, virus-like organisms and bacteria

- Methods in plant pathology

- Physiological, biochemical, ecological, genetic and economic aspects of plant pathology

- Disease appraisal and crop loss assessment

- Plant disease control, including disease-related crop management

Short reports of new or unusual records of plant diseases are welcomed, as are letters to the editor when these comment on matters relevant to plant pathology.

\section{Subscription Information}

Plant Pathology is published quarterly. Subscription rates for 1987 are $£ 73.50$ (UK), US $\$ 155.00$ (USA, Canada \& Japan), $£ 88.00$ (elsewhere) post free.

\section{Order Form}

Please tick the appropriate box and return to Blackwell Scientific Publications Ltd, P.o. Box 88, Oxford, England.

$\square$ I would like to subscribe to Plant Pathology

I wish to pay by cheque/money order (delese as necessary) and enclose the sum of

I wish to pay by Access/Barclaycard/VISA/Mastercard (delele as necessary)

Please debit my credit card no.

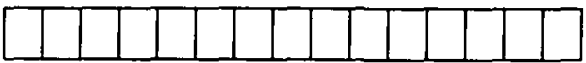

Expiry date

with the sum of

Signature.

Date

Please send me a specimen copy of Plant Pathology

Name

Address

Blackwell Scientific Publications

P.O. Box 88, Oxford, England

(i) 
Kirby, E. J. M., Porter, J. R., Day, W., Adam, Jill S., Appleyard, Margaret, Ayling, Sarah, Baker, C. K., Belford, R. K., Biscoe, P. V., Chapman, Anne, Fuller, M. P., Hampson, Janice, Hay, R. K. M., Matthews, S., Thompson, W. J., Weir, A. H., Willington, V. B. ANNE and WOOD, D. W. An analysis of primordium initiation in Avalon winter wheat crops with different sowing dates and at nine sites in England and Scotland

Williams, Ingrid H., Martin, A. P. and White, R. P. The effect of insect pollination on plant development and seed production in winter oil-seed rape (Brassica napus $\mathbf{L}$.) . . .

Addiscott, T. M. and Whitmore, A. P. Computer simulation of changes in soil mineral nitrogen and crop nitrogen during autumn, winter and spring .

OWEN, J. B. and WhITAKER, C. J. A comparison of cross-bred ewes raised from Welsh Mountain dams by three sire breeds: Cambridge, Border Leicester and Lleyn . . . . .

Brosh, A., Shkolnik, A. and Choshniak, I. Effects of infrequent drinking on the nitrogen metabolism of Bedouin goats maintained on different diets . . . . .

Sharma, R. C. and Sharma, H. C. Determination of fertilizer requirements of potato on the basis of soil tests in the north-western hills of India

Marriott, Carol A., Smith, Morag A. and Baird, M. A. The effect of sheep urine on clover performance in a grazed upland sward

SHORT NOTES

Sarkar, Apurba, Mitra, P. C., Roy, A. R. and Biswas, G. C. Tropical jute with coated and uncoated urea

Hunton, J. R., Flecker, Sally E. and Maxwell, W. M. C. Pregnancy rates following intra-uterine insemination with pellet or straw-frozen ram semen

Bhardwaj, H. L., Weaver, J. B. and Severson, R. F. Presence of water-soluble materials on cotton terminals as related to bollworm (Lepidoptera: Noctuidae) resistance

Ash, A. J. and Norton, B. W. Effect of DL-methionine supplementation on fleece growth by Australian cashmere goats

Esievo, K. A. N., Eduvie, L. O. and Fasanya, O. O. A. Reproductive performance of sheep and goats under native husbandry

Stevens, R. J. and Logan, H. J. Determination of the volatilization of ammonia from surface-applied cattle slurry by the micrometeorological mass balance method 


\section{THE JOURNAL OF AGRICULTURAL SCIENCE}

\section{CONTENTS}

\section{Vol. 109 Part 1 August 1987}

Loveland, P. J., Hazelden, J. and Sturdy, R. G. Chemical properties of salt-affected soils in north Kent and their relationship to soil instability

Fujihara, T., Ørskov, E. R., ReEDS, P. J. and KyLE, D. J. The effect of protein infusion on urinary excretion of purine derivatives in ruminants nourished by intragastric nutrition .

Elliott, R., Ash, A. J., Calderon-Cortes, F., Norton, B. W. and Bauchop, T. The influence of anaerobic fungi on rumen volatile fatty acid concentrations in vivo

BARBER, J. S. and Jessor, R. S. Factors affecting yield and quality in irrigated wheat

BiJAY-SiNGH and KaTYAL, J. C. Relative efficacy of some new urea-based nitrogen fertilizers for growing wetland rice on a permeable alluvial soil

Adinarayana, J. and Trwari, R. C. Nitrogen use efficiency of unirrigated barley as affected by shortage of water

OJEIFO, I. M. and LuCAS, E. O. The growth and development of Corchorus olitorius (L.) grown alone and intercropped with tomato (Lycopersicon esculentum (Mill.))

Arora, Y., NNADI, L. A. and Juo, A. S. R. Nitrogen efficiency of urea and calcium ammonium nitrate for maize (Zea mays) in humid and subhumid regions of Nigeria

HenNING, P. H. The effect of increased energy demand through walking exercise on intake and ruminal characteristics of sheep fed a roughage diet .

Narwal, S. S. and Malik, D. S. Effect of preceding crops on the nitrogen requirement of pearl millet and phosphorus requirement of chickpea .

Singh, B. B., Singh, U. P., Singh, R. M. and RAI, B. Genetic analysis of yield and yield components in field peas

SAHU, M. P. and SiNGH, H. G. Effect of sulphur on prevention of iron chlorosis and plant composition of groundnut on alkaline calcareous soils

Hipps, N. A. and HodGson, D. R. The effect of a slant-legged subsoiler on soil compaction and the growth of direct-drilled winter wheat

Arines, J. and SaInZ, Maria. Phosphorus sorption by acid soils: comparative study of some parameters

Droushiotis, D. N. and Wilman, D. Effects of harvesting programme and sowing date on the forage yield, digestibility, nitrogen concentration, tillers and crop fractions of barley in Cyprus

Porter, J. R., Kirby, E. J. M., Day, W., Adam, Jil.l S., Appleyard, Margaret, Ayling, Sarah, Baker, C. K., Beale, P., Belford, R. K., Biscoe, P. V., Chapman, Anne, Fuller, M. P., Hampson, Janice, Hay, R. K. M., Hough, M. N., Matthews, S., Thompson, W. J., Weir, A. H., Willington, V. B. AnNe and Wood, D. W. An analysis of morphological development stages in Avalon winter wheat crops with different sowing dates and at ten sites in England and Scotland

Continued inside back cover

(C) Cambridge University Press 1987

Copy ING. This journal is registered with the Copyright Clearance Center, 27 Congress Street, Salem, Mass. 01970. Organizations in the USA who are also registered with C.C.C. may therefore copy material (beyond the limits permitted by sections 107 and 108 of US copyright law) subject to payment to C.C.C. of the per-copy fee of $\$ 05.00$. This consent does not extend to multiple copying for promotional or commercial purposes. Code $0021-8596 / 87 \$ 5.00+0.00$.

ISI Tear Sheet Service, 3501 Market Street, Philadelphia, Pennsylvania 19106, USA, is authorized to supply single copies of separate articles for private use only.

For all other use, permission should be sought from Cambridge or the American Branch of Cambridge University Press. 